\title{
THE TRANSLATOR; A KEY FACTOR FOR TRANSLATION QUALITY; RECOMMENDATIONS FOR PRACTITIONERS
}

\begin{abstract}
Kirembwe Rashid Abdul Hamed*

Mohammad Najib Jaffar

Lubna Ābd. Rahman

\section{Faculty of Major Language Studies (FPBU), Universiti Sains Islam Malaysia} (USIM). ${ }^{*}$ Corresponding Author

Faculty of Major Language Studies (FPBU), Universiti Sains Islam Malaysia (USIM).

\section{ABSTRACT}

Faculty of Major Language Studies (FPBU), Universiti Sains Islam Malaysia (USIM).

ABSTRHCT

This research investigated translator characteristics and their influence in English-Arabic translation quality. The major problem was translation educators larking a clear-cut description of translator variables influencing English-Arabic translation quality. Thus, this research was administered to answer a major descriptive question about the extent to which translator characteristics influence English-Arabic translation quality. The study used a purposive sample selected from two countries; Malaysia and Libya. The validated and reliable questionnaires were distributed to a sample of professional translators sized $(n=30)$. The descriptive statistics was used for data analyses. The findings showed that translator's characteristics significantly influence the quality of English-Arabic translation at higher levels ranging from "Above Average" to "Excellent Standard". The findings also clarified that the better the translator characteristics assimilation in English-Arabic translation the better the TT quality and vice versa. It is further acceptable to hypothesize that translator characteristics significantly influence English-Arabic translation quality. Hence, it is recommendable for English-Arabic educators and practitioners to consider the influence of translator characteristics in the TT qualities.
\end{abstract}

\section{KEYWORDS : Translator; Factor; Translation, Quality; Source text ST; Target text TT}

\section{INTRODUCTION}

Translation is a process of transforming source text ST in to the target text TT where by a variety of linguistic and extralinguistic factors are consulted Kirembwe R.A.H \& M. Ohida 2018); (Kirembwe, Jaafar and Ahmad, 2014). The intervening context variables turn translation in to a complex activity (House, 2015). Traditionally, the translation of literary work requires a translator to be well articulated so that the feeling of the work may be converted to the TT. The affirmation on the influence of translator rather than the transmission of ST was been a quality proof for TT. Thus, translations aimed to enrich the native language rather than following the more rigid concepts of reliability (McGuire 1980).

However, the modern educational translation trends perceive the effectiveness of translator characteristics in terms of presage characteristics, process characteristics, context characteristics and product characteristics. The presage variables comprise of attributes and characteristics variables of translator. The context variables refer to the characteristics of translating environment which are not easy to control. The process variables are the translator's activities and behaviors. Such process variables are observable and controllable. The product variables are the TT outputs which result from the process activities (Kirembwe, 2004; Dunkin and Biddle, 1974; Weinstein and Mayer, 1984; Marton, 1976 and Marton, 1988).

Thus, translator's characteristics comprise of translators' formative experiences, socio-economic status, age and sex, training and vocational experiences. They also include permanent personality traits irrespective of their formative experiences, such as translation ability, intelligence motives, being well versed with the rules of both ST \& TT, being aware of the cultural backgrounds of both languages, informed about the translated subject context, possessing favorable literary sense, being able to critique the ST and being widely informed and knowledgeable (Kirembwe R.A.H., Yuslina M., M.N. Jaafar, H. Ahmad, 2013). Thus, the findings will alert translation practitioners about the sensitivity and effectiveness of translator's variables in translation research and practice.
Translation quality varies according to both language-arts translation ability and ST difficulty levels (Ehara, 2016); (Lörscher, 1992) and (Robinson \& Kenny 2012). When one tests the ability to translate, it is important to define exactly the elements that are to be measured. This task is not only include pointing out to the ability, knowledge or behavior in question but also involves breaking it down into its features. Thus, in order to measure the translator's professional ability we need to define both; the exact skills and sub-skills that constitute translator's professional ability. There is a need to explicitly mention exactly what knowledge and skill a translator needs to have in order to function as a qualified professional translator.

Thus, the current research was designed to analyze translator's characteristics that affect TT quality. These factors include and not limited to: gender, formative experiences, age, socio-economic status, training, vocational experiences, personality traits, language-arts translation ability, intelligence, intention, knowledge of ST rules, knowledge of TT rules, awareness of TT cultural background, awareness of translated subject, awareness of translated topic, awareness of translated context, possession of ST favorable literary sense, possession of TT favorable literary sense, ability to critique the ST and widely informed (Kirembwe et al, 2013); (Charles Forsdick \& Barbara Spadaro, 2019).

\section{LITERATURE}

This is was also observed that culture-conditioned preferences, translation focus, structuring and the use of routinized or adhoc tokens significantly influence TT output (Juliane House, 1997). Thus, the current research validated such information in wider perspective in terms of: TT rules, implementation of TT rules, TT material presentation mechanism, TT relevancy to present realities, TT material validity and TT material intention.

Savory (1957) suggested translator principles including reproducing the original words, ideas, sounding like ST initiator. The translation must reflect the original text style. The translation must possess the style of the translator; The translation should be read as contemporary to the original. 
However, for some reasons the TT may sound much greater than ST (Newmark, 1988). The translator rewrites an ST and reflects its ideology, poets and literature. Consequently the TT is a representation of ST (Venuti, L. 1995).

Simon (1996) stated that the female translator sees language as her feminine expression. Simon (1996) believes that the translator and writer's gender are presented in the text. Translators can reflect gender biases in the language which affects translator's choice of words and phrases. This is what Hatim and Munday (2004) called the translation project in which a female translator advocates and implements strategies to provoke femininity in TT. Hayeri, Navid (2014) also found that there is a huge difference between the words of men and women in the English language. Thus, there is a significant difference between male and female TTs.

The ability to engage with ST language arts and general literacy affect TT quality. This process encompasses sociocultural, linguistics and psychology aspects. The engagement with ST language arts extends to informative texts, expressive texts, spoken texts and audio texts (Venuti,2004); (Reiss 1971). Thus, Reiss (1977; 1989) argues that the quality of translation is ideal for engaging in the creative compositions that deem necessary to translate "expressive" texts where aesthetic dimensions of language are reflected in TT. Thus, the more knowledgeable the translator the better the TT.

Translator's experiences approximate an effective procedural memory that enables him/her to quickly process text (Douglas Robinson, 2005). There is a significant difference in TT quality done new versus inexperienced translators; Inexperienced translators perform better than inexperienced translators (Dehbandi \& Pourgharib, 2013). The research by Varzande \& Jadidi (2015) also concluded that translators' academic experience significantly influences the TT quality. Their results also showed that the TT quality by translators with academic experience was significantly better than those without academic experience.

Pym, Grin, Sfreddo and Chan (2012) Socio-economic influence the TT quality. it is a set of social cues that create the assumption of interpreters' experience the assumed value of experience. Socio-economic situations include: trustworthiness, professional exclusion, recognition, prestige, power, social status and quality. Daniel Gill (2009); (Emily Knowles and Helen Evans 2009). Hence, Robinson (1997) views the translator as a learner and indicates that translation is an intelligent activity that involves complex processes of conscious and unconscious training (Nord, 1991); (Kussmaul 1995); (Joanna Drugan \& Rebecca Tipton,2017).

What are usually considered to be the characteristics of translators constitute: good knowledge of their working languages, good mastery of conventional translation skills, sufficient knowledge of both ST and TT contents as well as the ability to translate different language-arts (Gile, 1995). Thus, Karwacka (2014) noted that the quality of translation is subject to training matrices for better TT quality. Varzande, (2016) also emphasizes that translators can get high-quality translation through continuous training.

Translation is a smart activity that requires translators to be creative because translation is a very complex process that requires different analysis including: semantic fields, grammatical structures, sociology, psychology and responding to cultural differences. Even translators from the most familiar texts, such as weather reports, may encounter unfamiliar situations and unexpected problems. Their intelligence enables them to translate quickly, reliably and enjoyably (Robinson, 1997. What a translator offers to a client is invaluable emotional, social and relational service (Robinson \& Kenny, 2012).
Language refers to the systematic symbols for communicating thoughts and feelings (Hornby, Jonathan Crowther, Kthryn Kavanagh and Michael Ashby, 1996). Therefore, language arts are the methodological variables of communication. This definition includes literature and rhetoric. Whereas, the arts of language as a symbol of general knowledge and literacy refer to the ideas, thoughts and feelings that are communicated. It includes critical thinking skills, self-perceptions of beauty and values, social skills demonstration, attitudes, reactions to different ideas and situations, theoretical and practical interpretations and scientific descriptions (Puckett, 1997).

Basing on the above definitions its hypothetically acceptable to assume that translation quality is influenced by levels of translators ability to translate ST language-arts, because language-arts are dynamic and the content of language-arts includes everything in the surroundings of a mankind (Sanacore and Joseph, 1996); (Kress, 1999). So translators ability to translate ST language-arts is considered essential for TT quality assessment (Kirembwe, Othman D.H.M., Fauzi M.M \& A. A. Samad, 2004).

\section{METHODOLOGY}

The method used in this study is Descriptive analytical method. This study used purposive sampling techniques and validated reliable questionnaire for the process of data collection which included the sample of professional translators in both Malaysia and Libya. The major translation constructs for translator characteristics were formulated and examined. The constructs were loaded with a respective questionnaire factors. The questionnaires were distributed to a sample of English-Arabic expert translators from two countries; Malaysia and Libya sized $(n=30)$. All questionnaire were completed and returned to the researcher. The total reliability coefficient of this Questionnaire was 0.95 for 20 factors.

The sample of English-Arabic expert translators were requested to rate the levels of perceived influence against the 20 validated translator's characteristics by adapting the 5point Likert rating scales which were structured in form of questionnaire with a headachy of: very poor, poor, good, very good and excellent. The transitional scoring selection pattern was: (very poor, poor, good, very good and excellent). (Gabriela Saldanha, Sharon O'Brien, 2014).

These scales were explicitly meant to imply the following qualities: 1-(Very Poor Standard) corresponds with inappropriate or not acceptable; 2-(Poor Standard) corresponds with below average quality; 3-(Good Standard) corresponds with average quality; 4-(Very Good Standard) corresponds with above-average quality; 5-(Excellent Standard) corresponds with highest translation quality (Pym, Orrego-Carmona, \& Torres Simón, 2015); (Huertas-Barros, Elsa, Vandepitte, Sonia, Iglesias-Fernández, Emilia, 2018) and (Patton, 1990).

\section{ANALYSIS}

As the nature of this research determined the process of data analyses depended much on descriptive statistics; whereby frequencies, mean averages were applied to summarize the data. Where upon, Pearson product moment correlation coefficient analyses were applied to predict the hypothetical correlation assumptions inherent in the translator's variables. The descriptive statistics below summarize translator characteristics data where it clarifies that translator characteristics influence the quality of translation differently. This is clearly summarized in the following Table 1; Descriptive Statistics for Translator characteristics Influencing EnglishArabic Translation Quality.

TABLE 1. Descriptive Statistics for Translator's Characteristics Influencing English-Arabic Translation Quality. 


\begin{tabular}{|l|r|r|r|r|r|}
\hline \hline & N & $\begin{array}{c}\text { Mini } \\
\text { mum }\end{array}$ & $\begin{array}{l}\text { Maxi } \\
\text { mum }\end{array}$ & \multicolumn{2}{|c|}{ Mean } \\
\hline & $\begin{array}{r}\text { Stat } \\
\text { istic }\end{array}$ & $\begin{array}{c}\text { Stati } \\
\text { stic }\end{array}$ & $\begin{array}{c}\text { Stati } \\
\text { stic }\end{array}$ & $\begin{array}{c}\text { Statis } \\
\text { tic }\end{array}$ & $\begin{array}{c}\text { Std. } \\
\text { Error }\end{array}$ \\
\hline Gender & 30 & 3.00 & 5.00 & 3.5333 & .13333 \\
\hline Formative Experiences & 30 & 3.00 & 5.00 & 4.1333 & .13333 \\
\hline Age & 30 & 3.00 & 5.00 & 3.5667 & .11430 \\
\hline Socio-Economic Status & 30 & 3.00 & 5.00 & 3.6000 & .14061 \\
\hline Training & 30 & 4.00 & 5.00 & 4.7333 & .08212 \\
\hline Vocational Experiences & 30 & 4.00 & 5.00 & 4.5667 & .09202 \\
\hline Personality Traits & 30 & 3.00 & 5.00 & 3.5333 & .12441 \\
\hline $\begin{array}{l}\text { Language-Arts Translation } \\
\text { Ability }\end{array}$ & 30 & 4.00 & 5.00 & 4.6000 & .09097 \\
\hline Intelligence & 30 & 4.00 & 5.00 & 4.7000 & .08510 \\
\hline Translator's Intention & 30 & 3.00 & 5.00 & 4.0000 & .12685 \\
\hline $\begin{array}{l}\text { Translator's Knowledge of } \\
\text { ST rules }\end{array}$ & 30 & 4.00 & 5.00 & 4.7000 & .08510 \\
\hline $\begin{array}{l}\text { Translator's Knowledge of } \\
\text { TT rules }\end{array}$ & 30 & 4.00 & 5.00 & 4.7333 & .08212 \\
\hline $\begin{array}{l}\text { Translator's Awareness of } \\
\text { TT Cultural Background }\end{array}$ & 30 & 3.00 & 5.00 & 3.4667 & .11480 \\
\hline $\begin{array}{l}\text { Translator's Awareness of } \\
\text { translated subject }\end{array}$ & 30 & 4.00 & 5.00 & 4.4333 & .09202 \\
\hline $\begin{array}{l}\text { Translator's Awareness of } \\
\text { Translated Topic }\end{array}$ & 30 & 4.00 & 5.00 & 4.5000 & .09285 \\
\hline $\begin{array}{l}\text { Translator's Awareness of } \\
\text { Translated Context }\end{array}$ & 30 & 3.00 & 5.00 & 3.9333 & .12625 \\
\hline $\begin{array}{l}\text { Translator's Possession of } \\
\text { ST Favorable Literary } \\
\text { Sense }\end{array}$ & 30 & 3.00 & 5.00 & 4.0000 & .11744 \\
\hline $\begin{array}{l}\text { Translator's Possession of } \\
\text { TT favorable literary sense }\end{array}$ & 30 & 3.00 & 5.00 & 3.8667 & .12441 \\
\hline $\begin{array}{l}\text { Translator's Ability to } \\
\text { Critique the ST }\end{array}$ & 30 & 3.00 & 5.00 & 3.8667 & .12441 \\
\hline $\begin{array}{l}\text { Translator's Widely } \\
\text { Informed }\end{array}$ & 30 & 3.00 & 5.00 & 4.0333 & .13965 \\
\hline Valid N (listwise) & 30 & & & & \\
\hline
\end{tabular}

Source: Authors' Analysis SPSS Output.

The Table 1. above clarifies that experts in English-Arabic translation explicitly agree that the translator characteristics influence English-Arabic translation quality at a higher level; (Very Good); (above-average), which means that the more the consideration of translator characteristics in translation the better the TT quality and vice versa. This was manifested by experts ratings "Above the average"; 4/5 for all the characteristics marking that the highest point on the scale was "5". The Table (1) above show that the means of translator characteristics influence in the quality of English-Arabic translation are clustered at higher levels ranging form "Above Average" to "Excellent Level".

The arithmetic means of translator characteristics influence in the quality of English-Arabic translation are as described as follows: gender $\mu=3.53$ formative experiences $\mu=4.13$; age $\mu$ $=3.57$; socio-economic status $\mu=3.60$; training $\mu=4.73$; vocational experiences $\mu=4.57$; personality traits $\mu=3.53$; language-arts translation ability factor $\mu=4.60$; intelligence $\mu$ $=4.70$; translator's intention $\mu=4.00$; translator's knowledge of ST rules $\mu=4.70$; translator's knowledge of TT rules $\mu=$ 4.73; translator's awareness of TT cultural background $\mu=$ 3.47; translator's awareness of translated subject $\mu=4.43$; translator's awareness of translated topic $\mu=4.50$; translator's awareness of translated context $\mu=3.93$; translator's possession of ST favourable literary sense $\mu=$ 4.00; translator's possession of TT favourable literary sense $\mu$
$=3.87$; translator's ability to critique the ST $\mu=3.87$; translator's widely informed $\mu=4.03$. This phenomenon is clearly elaborated in the following frequency tables; 2-21:

\begin{tabular}{|l|l|l|l|l|l|}
\hline \multicolumn{6}{|c|}{ TABLE 2. Gender as Translation Quality Factor } \\
\hline \multicolumn{2}{|c|}{} & Frequency & Percent & $\begin{array}{l}\text { Valid } \\
\text { Percent }\end{array}$ & $\begin{array}{l}\text { Cumulative } \\
\text { Percent }\end{array}$ \\
\hline \multirow{3}{*}{ Valid } & Good & 18 & 60 & 60 & 60 \\
\cline { 2 - 7 } & Very good & 8 & 26.7 & 26.7 & 86.7 \\
\cline { 2 - 7 } & Excellent & 4 & 13.3 & 13.3 & 100 \\
\cline { 2 - 6 } & Total & 30 & 100 & 100 & \\
\hline
\end{tabular}

The above table 2 shows the frequency of expert rating on the influence of gender in English-Arabic translation quality, involving: good $n=18,60 \%$; very good $n=8,26.7 \%$ and excellent $n=4,13.3 \%$. Total raters $n=30,100 \%$.

\begin{tabular}{|l|l|l|l|l|l|}
\hline \multicolumn{6}{|c|}{ TABLE 3. Formative Experiences as Translation Quality } \\
Factor \\
\hline \multirow{2}{*}{} & Frequency & Percent & $\begin{array}{l}\text { Valid } \\
\text { Percent }\end{array}$ & $\begin{array}{l}\text { Cumulative } \\
\text { Percent }\end{array}$ \\
\hline \multirow{3}{*}{ Valid } & Good & 6 & 20 & 20 & 20 \\
\cline { 2 - 6 } & Very good & 14 & 46.7 & 46.7 & 66.7 \\
\cline { 2 - 6 } & Excellent & 10 & 33.3 & 33.3 & 100 \\
\cline { 2 - 6 } & Total & 30 & 100 & 100 & \\
\hline
\end{tabular}

The above table 3 shows the frequency of expert rating on the influence of formative experiences in English-Arabic translation quality, involving: good $n=6,20 \%$; very good $\mathrm{n}=14,46.7 \%$ and excellent $\mathrm{n}=10,33.3 \%$. Total raters $\mathrm{n}=30$, $100 \%$.

\begin{tabular}{|l|l|l|l|l|l|}
\hline \multicolumn{6}{|c|}{ TABLE 4. Age as Translation Quality Factor } \\
\hline \multicolumn{2}{|c|}{} & Frequency & Percent & $\begin{array}{l}\text { Valid } \\
\text { Percent }\end{array}$ & $\begin{array}{l}\text { Cumulative } \\
\text { Percent }\end{array}$ \\
\hline \multirow{3}{*}{ Valid } & Good & 15 & 50 & 50 & 50 \\
\cline { 2 - 7 } & Very Good & 13 & 43.3 & 43.3 & 93.3 \\
\cline { 2 - 6 } & Excellent & 2 & 6.7 & 6.7 & 100 \\
\cline { 2 - 6 } & Total & 30 & 100 & 100 & \\
\hline
\end{tabular}

The above table 4 shows the frequency of expert rating on the influence of age in English-Arabic translation quality, involving: good $n=15,50 \%$; very good $n=13,43.3 \%$ and excellent $\mathrm{n}=2,6.7 \%$. Total raters $\mathrm{n}=30,100 \%$.

\begin{tabular}{|l|l|l|l|l|l|}
\hline \multicolumn{3}{|c|}{ TABLE 5. Socio-Economic Status as Translation Quality } \\
Factor \\
\hline \multirow{2}{*}{} & Frequency & Percent & $\begin{array}{l}\text { Valid } \\
\text { Percent }\end{array}$ & $\begin{array}{l}\text { Cumulative } \\
\text { Percent }\end{array}$ \\
\hline \multirow{3}{*}{ Valid } & Good & 17 & 56.7 & 56.7 & 56.7 \\
\cline { 2 - 6 } & Very Good & 8 & 26.7 & 26.7 & 83.3 \\
\cline { 2 - 6 } & Excellent & 5 & 16.7 & 16.7 & 100 \\
\cline { 2 - 6 } & Total & 30 & 100 & 100 & \\
\hline
\end{tabular}

The above table 5 shows the frequency of expert rating on the influence of socio-economic status in English-Arabic translation quality, involving: good $n=17,56.7 \%$; very good $\mathrm{n}=8,26.7 \%$ and excellent $\mathrm{n}=5,16.7 \%$. Total raters $\mathrm{n}=30$, $100 \%$.

\begin{tabular}{|l|l|l|l|l|l|}
\hline \multicolumn{5}{|c|}{ Table 6: Training As Translation Quality Factor } \\
\hline \multicolumn{2}{|c|}{} & Frequency & Percent & $\begin{array}{l}\text { Valid } \\
\text { Percent }\end{array}$ & $\begin{array}{l}\text { Cumulative } \\
\text { Percent }\end{array}$ \\
\hline \multirow{3}{*}{ Valid } & Very Good & 8 & 26.7 & 26.7 & 26.7 \\
\cline { 2 - 6 } & Excellent & 22 & 73.3 & 73.3 & 100 \\
\cline { 2 - 6 } & Total & 30 & 100 & 100 & \\
\hline
\end{tabular}

The above table 6 shows the frequency of expert rating on the influence of training in English-Arabic translation quality, involving: very good $n=8,26.7 \%$ and excellent $n=22,73.3 \%$. Total raters $\mathrm{n}=30,100 \%$.

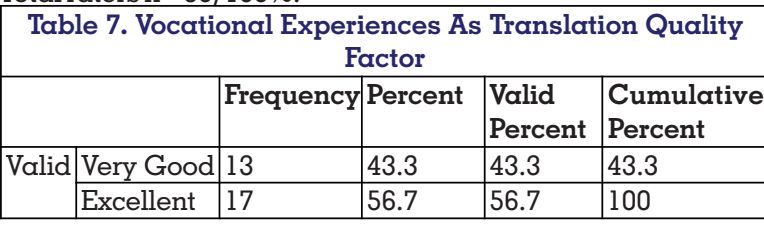




\begin{tabular}{l|l|l|l} 
Total & 30 & 100 & 100
\end{tabular}

The above table 7 shows the frequency of expert rating on the influence of vocational experiences in English-Arabic translation quality, involving: very good $n=13,43.3 \%$ and excellent $\mathrm{n}=17,56.7 \%$. Total raters $\mathrm{n}=30,100 \%$.

Table 8. Personality Traits As Translation Quality Factor

\begin{tabular}{|l|l|l|l|l|l|}
\hline \multicolumn{2}{|c|}{} & Frequency & Percent & $\begin{array}{l}\text { Valid } \\
\text { Percent }\end{array}$ & $\begin{array}{l}\text { Cumulative } \\
\text { Percent }\end{array}$ \\
\hline \multirow{3}{*}{ Valid } & Good & 17 & 56.7 & 56.7 & 56.7 \\
\cline { 2 - 6 } & Very Good & 10 & 33.3 & 33.3 & 90 \\
\cline { 2 - 6 } Excellent & 3 & 10 & 10 & 100 \\
\cline { 2 - 6 } & Total & 30 & 100 & 100 & \\
\hline
\end{tabular}

The above table 8 shows the frequency of expert rating on the influence of personality traits in English-Arabic translation quality, involving: good $n=17,56.7 \%$; very good $n=10,33.3 \%$ and excellent $\mathrm{n}=3,10 \%$. Total raters $\mathrm{n}=30,100 \%$.

Table 9. Language-arts Translation Äbility Âs Translation Quality Factor

\begin{tabular}{|l|l|l|l|l|l|}
\hline \multicolumn{2}{|c|}{} & Frequency & Percent & $\begin{array}{l}\text { Valid } \\
\text { Percent }\end{array}$ & $\begin{array}{l}\text { Cumulative } \\
\text { Percent }\end{array}$ \\
\hline \multirow{3}{*}{ Valid } & Very Good & 12 & 40 & 40 & 40 \\
\cline { 2 - 6 } & Excellent & 18 & 60 & 60 & 100 \\
\cline { 2 - 6 } & Total & 30 & 100 & 100 & \\
\hline
\end{tabular}

The above table 9 shows the frequency of expert rating on the influence of language-arts translation ability in EnglishArabic translation quality, involving: $n=$ very good $n=12,40 \%$ and excellent $n=18,60 \%$. Total raters $n=30,100 \%$.

Table 10. Intelligence Âs Translation Quality Factor

\begin{tabular}{|l|l|l|l|l|l|}
\hline \multicolumn{2}{|c|}{} & Frequency & Percent & $\begin{array}{l}\text { Valid } \\
\text { Percent }\end{array}$ & $\begin{array}{l}\text { Cumulative } \\
\text { Percent }\end{array}$ \\
\hline \multirow{3}{*}{ Valid } & Very Good & 9 & 30 & 30 & 30 \\
\cline { 2 - 6 } & Excellent & 21 & 70 & 70 & 100 \\
\cline { 2 - 6 } & Total & 30 & 100 & 100 & \\
\hline
\end{tabular}

The above table 10 shows the frequency of expert rating on the influence of intelligence in English-Arabic translation quality, involving: very good $n=9,30 \%$ and excellent $n=21,70 \%$. Total raters $\mathrm{n}=30,100 \%$.

\begin{tabular}{|l|l|l|l|l|l|}
\hline \multicolumn{6}{|c|}{ Table 11. Translator's Intention As Translation Quality } \\
\multicolumn{2}{|c|}{ Factor } \\
\hline \multirow{2}{*}{} & Frequency & Percent & $\begin{array}{l}\text { Valid } \\
\text { Percent }\end{array}$ & $\begin{array}{l}\text { Cumulative } \\
\text { Percent }\end{array}$ \\
\hline \multirow{4}{*}{ Valid } & Good & 7 & 23.3 & 23.3 & 23.3 \\
\cline { 2 - 6 } & Very Good & 16 & 53.3 & 53.3 & 76.7 \\
\cline { 2 - 6 } & Excellent & 7 & 23.3 & 23.3 & 100 \\
\cline { 2 - 6 } & Total & 30 & 100 & 100 & \\
\hline
\end{tabular}

The above table 11 shows the frequency of expert rating on the influence of translator's intention in English-Arabic translation quality, involving: good $n=23.37 \%$; very good $n=16,53.3 \%$ and excellent $n=7,23.3 \%$. Total raters $n=30,100 \%$.

\begin{tabular}{|l|l|l|l|l|l|}
\hline \multicolumn{5}{|c|}{ Table 12. Translator's Knowledge Of St Rules } \\
\hline \multicolumn{2}{|c|}{} & Frequency & Percent & $\begin{array}{l}\text { Valid } \\
\text { Percent }\end{array}$ & $\begin{array}{l}\text { Cumulative } \\
\text { Percent }\end{array}$ \\
\hline \multirow{3}{*}{ Valid } & Very Good & 9 & 30 & 30 & 30 \\
\cline { 2 - 6 } & Excellent & 21 & 70 & 70 & 100 \\
\cline { 2 - 6 } & Total & 30 & 100 & 100 & \\
\hline
\end{tabular}

The above table 12 shows the frequency of expert rating on the influence of translator's knowledge of ST rules in EnglishArabic translation quality, involving: very good $n=9,30 \%$ and excellent $\mathrm{n}=21,70 \%$. Total raters $\mathrm{n}=30,100 \%$.

\begin{tabular}{|l|l|l|l|l|l|}
\hline \multicolumn{5}{|c|}{ Table 13. Translator's Knowledge Of TT Rules } \\
\hline \multicolumn{2}{|c|}{} & Frequency & Percent & $\begin{array}{l}\text { Valid } \\
\text { Percent }\end{array}$ & $\begin{array}{l}\text { Cumulative } \\
\text { Percent }\end{array}$ \\
\hline \multirow{3}{*}{ Valid } & Very Good & 8 & 26.7 & 26.7 & 26.7 \\
\cline { 2 - 6 } & Excellent & 22 & 73.3 & 73.3 & 100 \\
\cline { 2 - 6 } & Total & 30 & 100 & 100 & \\
\hline
\end{tabular}

The above table 13 shows the frequency of expert rating on the influence of translator's knowledge of TT rules in English-
Arabic translation quality, involving: very good $n=8,26.7 \%$ and excellent $n=22,73.3 \%$. Total raters $n=30,100 \%$.

\begin{tabular}{|l|l|l|l|l|l|}
\hline \multicolumn{6}{|c|}{ Table 14. Translator's Awareness Of TT Cultural } \\
Background \\
\hline \multirow{2}{*}{} & Frequency & Percent & $\begin{array}{l}\text { Valid } \\
\text { Percent }\end{array}$ & $\begin{array}{l}\text { Cumulative } \\
\text { Percent }\end{array}$ \\
\hline \multirow{3}{*}{ Valid } & Good & 18 & 60 & 60 & 60 \\
\cline { 2 - 6 } & Very Good & 10 & 33.3 & 33.3 & 93.3 \\
\cline { 2 - 6 } & Excellent & 2 & 6.7 & 6.7 & 100 \\
\cline { 2 - 6 } & Total & 30 & 100 & 100 & \\
\hline
\end{tabular}

The above table 14 shows the frequency of expert rating on the influence of translator's awareness of TT cultural background in English-Arabic translation quality, involving: good $\mathrm{n}=18$, $60 \%$; very good $n=10,33.3 \%$ and excellent $n=2,6.7 \%$. Total raters $\mathrm{n}=30,100 \%$.

\begin{tabular}{|l|l|l|l|l|l|}
\hline \multicolumn{2}{|c|}{ Table 15. Translator's Awareness Of Translated Subject } \\
\hline \multicolumn{2}{|c|}{} & Frequency & Percent & $\begin{array}{l}\text { Valid } \\
\text { Percent }\end{array}$ & $\begin{array}{l}\text { Cumulative } \\
\text { Percent }\end{array}$ \\
\hline \multirow{3}{*}{ Valid } & Very Good & 17 & 56.7 & 56.7 & 56.7 \\
\cline { 2 - 6 } & Excellent & 13 & 43.3 & 43.3 & 100 \\
\cline { 2 - 6 } & Total & 30 & 100 & 100 & \\
\hline
\end{tabular}

The above table 15 shows the frequency of expert rating on the influence of translator's awareness of translated subject in English-Arabic translation quality, involving: very good $\mathrm{n}=17$, $56.7 \%$ and excellent $n=13,43.3 \%$. Total raters $n=30,100 \%$.

\begin{tabular}{|l|l|l|l|l|l|}
\hline \multicolumn{6}{|c|}{ Table 16. Translator's Awareness Of Translated Topic } \\
\hline \multicolumn{2}{|c|}{} & Frequency & Percent & $\begin{array}{l}\text { Valid } \\
\text { Percent }\end{array}$ & $\begin{array}{l}\text { Cumulative } \\
\text { Percent }\end{array}$ \\
\hline \multirow{3}{*}{ Valid } & Very Good & 15 & 50 & 50 & 50 \\
\cline { 2 - 6 } & Excellent & 15 & 50 & 50 & 100 \\
\cline { 2 - 6 } & Total & 30 & 100 & 100 & \\
\hline
\end{tabular}

The above table 16 shows the frequency of expert rating on the influence of translator's awareness of translated topic in English-Arabic translation quality, involving: very good $n=15$, $50 \%$ and excellent $n=15,50 \%$. Total raters $n=30,100 \%$.

\begin{tabular}{|l|l|l|l|l|l|}
\hline \multicolumn{3}{|c|}{ Table 17. Translator's Awareness Of Translated Context } \\
\hline \multicolumn{2}{|l|}{} & Frequency & Percent & $\begin{array}{l}\text { Valid } \\
\text { Percent }\end{array}$ & $\begin{array}{l}\text { Cumulative } \\
\text { Percent }\end{array}$ \\
\hline \multirow{3}{*}{ Valid } & Good & 8 & 26.7 & 26.7 & 26.7 \\
\cline { 2 - 6 } & Very Good & 16 & 53.3 & 53.3 & 80 \\
\cline { 2 - 6 } & Excellent & 6 & 20 & 20 & 100 \\
\cline { 2 - 6 } & Total & 30 & 100 & 100 & \\
\hline
\end{tabular}

The above table 17 shows the frequency of expert rating on the influence of translator's awareness of translated context in English-Arabic translation quality, involving: good $\mathrm{n}=8$, $26.7 \%$ very good $n=16,53.3 \%$ and excellent $n=6,20 \%$. Total raters $\mathrm{n}=30,100 \%$.

\begin{tabular}{|c|c|c|c|c|c|}
\hline \multicolumn{6}{|c|}{$\begin{array}{r}\text { Table 18. Translator's Possession } \\
\text { Sense }\end{array}$} \\
\hline & & Frequency & Percent & \begin{tabular}{|l|} 
Valid \\
Percent
\end{tabular} & \begin{tabular}{|l|} 
Cumulative \\
Percent
\end{tabular} \\
\hline \multirow[t]{4}{*}{ Valid } & Good & 6 & 20 & 20 & 20 \\
\hline & Very Good & 18 & 60 & 60 & 80 \\
\hline & Excellent & 6 & 20 & 20 & 100 \\
\hline & Total & 30 & 100 & 100 & \\
\hline
\end{tabular}

The above table 18 shows the frequency of expert rating on the influence of translator's possession of ST favorable literary sense in English-Arabic translation quality, involving: good $n=6,20 \%$; very good $n=18,60 \%$ and excellent $n=6,20 \%$. Total raters $\mathrm{n}=30,100 \%$.

\begin{tabular}{|c|c|c|c|c|c|}
\hline & & & ense & & \\
\hline & & Frequency & Percent & \begin{tabular}{|l} 
Valid \\
Percent
\end{tabular} & \begin{tabular}{|l|} 
Cumulative \\
Percent
\end{tabular} \\
\hline Valid & Good & 9 & 30 & 30 & 30 \\
\hline & Very Good & 16 & 53.3 & 53.3 & 83.3 \\
\hline & Excellent & 5 & 16.7 & 16.7 & 100 \\
\hline & Total & 30 & 100 & 100 & \\
\hline
\end{tabular}


The above table 19 shows the frequency of expert rating on the influence of translator's possession of TT favorable literary sense in English-Arabic translation quality, involving: good $n=9,30 \%$; very good $n=16,53.3 \%$ and excellent $n=16,53.3 \%$. Total raters $\mathrm{n}=30,100 \%$.

\begin{tabular}{|l|l|l|l|l|l|}
\hline \multicolumn{6}{|c|}{ Table 20. Translator's Ability To Critique The ST } \\
\hline \multirow{6}{*}{ Valid } & Frequency & Percent & $\begin{array}{l}\text { V a l i d } \\
\text { Percent }\end{array}$ & \multicolumn{3}{l|}{ Cumulative Percent } \\
\cline { 2 - 6 } & Good & 9 & 30 & 30 & 30 \\
\cline { 2 - 6 } & Very Good & 16 & 53.3 & 53.3 & 83.3 \\
\cline { 2 - 6 } & Excellent & 5 & 16.7 & 16.7 & 100 \\
\cline { 2 - 6 } & Total & 30 & 100 & 100 & \\
\hline
\end{tabular}

The above table 20 shows the frequency of expert rating on the influence of translator's ability to critique the ST in EnglishArabic translation quality, involving: good $n=9,30 \%$; very good $n=16,53.3 \%$ and excellent $n=5,16.7 \%$. Total raters $\mathrm{n}=30,100 \%$.

\begin{tabular}{|c|}
\hline Table 21. Translators Wide Information As Translation Quality \\
Factor
\end{tabular}

\begin{tabular}{|l|l|l|l|l|l|}
\hline \multirow{4}{*}{ Valid } & Frequency & Percent & $\begin{array}{l}\text { V a I i d } \\
\text { Percent }\end{array}$ & \multicolumn{2}{|l|}{ Cumulative Percent } \\
\cline { 2 - 6 } & Good & 8 & 26.7 & 26.7 & 26.7 \\
\cline { 2 - 6 } & Very Good & 13 & 43.3 & 43.3 & 70 \\
\cline { 2 - 6 } & Excellent & 9 & 30 & 30 & 100 \\
\cline { 2 - 6 } & Total & 30 & 100 & 100 & \\
\hline
\end{tabular}

The above table 21 shows the frequency of expert rating on the influence of translators wide information in English-Arabic translation quality, involving: good $n=8,26.7 \%$ very good $\mathrm{n}=13,43.3 \%$ and excellent $\mathrm{n}=9,30 \%$. Total raters $\mathrm{n}=30$, $100 \%$.

The tables 2-21 indicate that translator's characteristics are effective and considerable for English-Arabic translation quality. Such observations alert English-Arabic educators and practitioners to consider the sensitivity of translator's characteristics in their TT output qualities. For more insight on this point the following Table 22 displays 20 non-directional correlations among translator's variables that influence the quality of English-Arabic translation.

Table 22: Correlations Among Translator's Variables

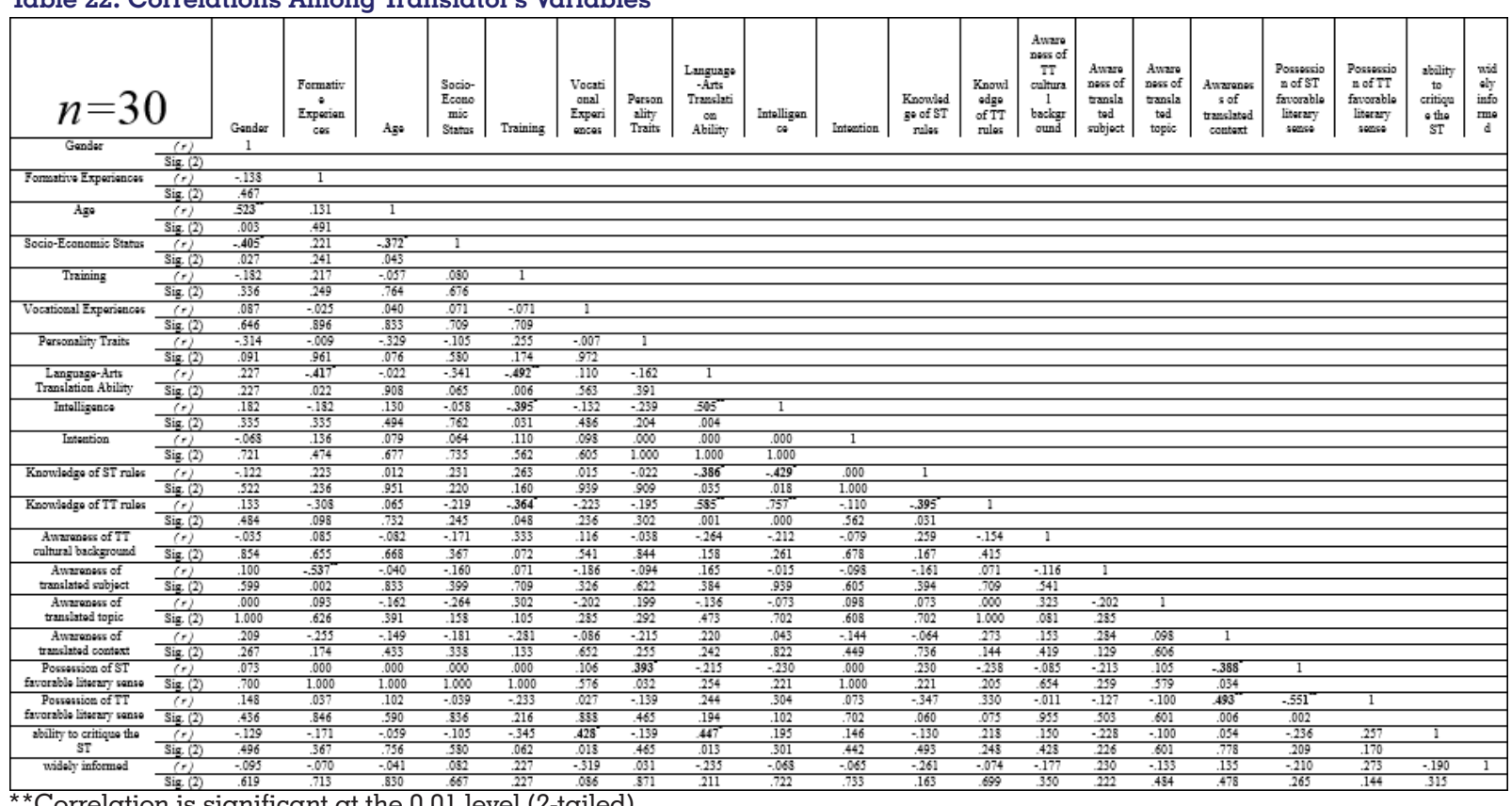

${ }^{* *}$ Correlation is significant at the 0.01 level (2-tailed).

${ }^{*}$ Correlation is significant at the 0.05 level (2-tailed).

The above table 22 describes 20 non-directional correlations among translator's variables that influence the quality of English-Arabic translation. On one hand, the table displays 8 positions of significant correlation among translator's variables at $n=30, \alpha 2,0.01$. On an other hand, the Table 22 describes 12 significant correlation among translator's variables at $n=30, \alpha 2,0.05$.

The 8 significant correlation among translator's variables at $n=30, \alpha 2,0.01$ include: age with gender $(r)=0.523$; languagearts' translation ability with training $(r)=-0.492$; intelligence with language-arts translation ability $(r)=0.505$; knowledge of TT rules with language-arts translation ability $(r)=0.585$; knowledge of TT rules with intelligence $(r)=0.757$; awareness of translated subject with formative experiences $(r)=-0.537$; possession of TT favorable literary sense with awareness of translated context $(r)=0.493$ and possession of TT favorable literary sense with possession of ST favorable literary sense $(r)=-0.551$.

While 12 positions of significant correlations among translator's variables at $n=30, \alpha 2,0.05$ include the following variables: socio-economic status with gender $(r)=-0.405$; socio-economic status with age $(r)=0.372$; language-arts translation ability with formative experiences $(r)=-0.417$; intelligence with training $(r)=-0.395$; knowledge of ST rules with language-arts translation ability $(r)=-0.386$; knowledge of ST rules with intelligence $(r)=-0.429$; knowledge of TT rules with training $(r)=-0.364$; knowledge of TT rules with knowledge of ST rules $(r)=-0.395$; possession of ST favorable literary sense with personality traits $(r)=0.393$; possession of ST favorable literary sense with awareness of translated context $(r)=0.388$; ability to critique the ST with vocational experiences $(r)=0.428$ and ability to critique the ST with language-arts translation ability $(r)=0.447$.

\section{FINDINGS}

The findings indicate that translator's characteristics are highly considerable for English-Arabic translation quality. The experts' ratings for translator's characteristics were assembled around "good, "very good and "excellent standards". Thus, translator's characteristics significantly influence the quality of English-Arabic translation at "Above Average" to "Excellent Standard"; The findings also yielded 20 significant non-directional correlations among translator's variables influencing the quality of English-Arabic translation;

On one hand, findings yielded 8 significant correlations 
among translator's variables influencing English-Arabic translation quality at $n=30, \alpha 2,0.01$. On an other hand, findings yielded 12 significant correlation among translator's variables influencing the quality of English-Arabic translation at $n=30, \alpha 2,0.05$. Thus, it is hypothetically acceptable to state that the better the translator's characteristics favor for EnglishArabic translation the better the TT output quality and vice versa.

\section{CONCLUSION}

This research investigated translator's variables influencing English-Arabic translation quality. The finding of this Thus, translator's characteristics significantly influence the quality of English-Arabic translation at "Above Average" to "Excellent Standard"; The findings also yielded 20 significant nondirectional correlations among translator's variables influencing the quality of English-Arabic translation; On one hand, findings yielded 8 significant correlations among translator's variables influencing English-Arabic translation quality at $n=30, \alpha 2,0.01$.

On an other hand, findings yielded 12 significant correlation among translator's variables influencing the quality of English-Arabic translation at $n=30, \alpha 2,0.05$. Thus, it is hypothetically acceptable to state that the better the translator's characteristics favor for English-Arabic translation the better the TT output quality and vice versa. Hence, it is recommendable for English-Arabic educators and practitioners to consider the influence of translator's variables in the TT qualities. This study has been pre-experimental in nature and the reported relationships are non-directional. Thus, it is recommendable for subsequent translation educators and practitioner to carry out causal comparative research in order to find out the true directions of the reported relationships so as to gain more empirical information about English-Arabic translator's variables as well as getting better control over the translator's variables.

\section{REFERENCES}

1. A.S Hornby, Jonathan Crowther, Kthryn Kavanagh and Michael Ashby, (1996). Oxford Advanced Learner's Dictionary of Current English, Fifth Edition, Oxford University Press, Walton Street, Oxford New York USA.

2. Charles Forsdick \& Barbara Spadaro (2019). Introduction: thematic approaches to translation, The Translator.25:4, 303-310, DOI: 10.1080/13556509.2019.1766902

3. Chau, Simon, (1984). "Hermeneutics and the Translator: The ontological dimension of translating "in Multilingua 3, 2, 71-77.

4. De Borba, M. C. S. Simon, Sherry, (1997). Gender in Translation-Cultural Identity and the Politics of Transmission. Cadernos de Traduçao, 1(2), 508-509.

5. Dehbandi, Z. \& Pourgharib, B. (2013). The Difference in Translation Quality of Undergraduate Translation Students and Experienced Translators in Narrative Text. Journal of Language Sciences \& Linguistics. Vol, 1(1), 12-15.

6. Dunkin M.J. \& Biddle B.J. (1974). The Study of Teaching. Holt, Rhinehart and Winston, Inc.

7. Ehara, Y., Baba, Y., Utiyama, M., \& Sumita, E. (n.d.). Assessing Translation Ability through Vocabulary Ability Assessment. https: //pdfs. Semantic scholar. org/47ea/223867dbe59f73f4f8edlf429cfdb7abd68e.pdf.

8. Gabriela Saldanha, Sharon O'Brien. (2014). Research Methodologies in Translation Studies: Routledge.

9. Gile, D. (2009). Basic Concepts and Models for Interpreter and Translator Training (Rev. ed). Amsterdam; Philadelphia: John Benjamins Pub. Co.

10. Hatim \& Mason. (2013). Discourse and the Translator, Routledge. London \& New York

11. Hatim, B. \& Mason, I. (1990): Discourse and the Translator. Essex: Longman.

12. Hatim, B. \& Mason, I. (1997). Translator as Communicator. Taylor \& Francis eLibrary

13. Hatim, B. \& Mason, I. (2013). Discourse and the translator. London. New York:

14. Holz-Mänttäri, Justa. (1984). Translatorisches Handeln. Theorie und Methode. Helsinki: Academia Scientiarum Fennica.

15. House, J. (2001). Translation Quality Assessment: Linguistic Description Versus Social Evaluation. Meta: Journal des traducteurs, 46(2), 243. http: //doi.org/10.7202/00314lar.

16. House, J. (2015). Translation Quality Assessment: Past and Present. Abingdon, Oxon, England ; New York: Routledge.

17. Huertas-Barros, Elsa, Vandepitte, Sonia, Iglesias-Fernández, Emilia. ( 2018). Quality Assurance and Assessment Practices in Translation and Interpreting. Advances in Linguistics and Communication Studies (2372-109X): IGI Global.

18. Joanna Drugan \& Rebecca Tipton (2017) Translation, ethics and social responsibility, The Translator, 23:2, 119-125, DOI: 10.1080/13556509.2017.13 27008.

19. Kirembwe R.A.H., M.N. Jaffar, Lubna A.R \& M. Ohida (2018). Translation Quality Scales (A Comprehensive Pilot Report on Translation Quality
Assessment Tools). Ph.D Research Data Archives 2018. Faculty of Major Language Studies (FPBU). Universiti Sains Islam Malaysia; (USIM).

20. Kirembwe R.A.H, Jaafar M. N, Ahmad H. (2014). Encyclopedia of LugandaEnglish-Arabic Wordlist: Penerbit USIM http://mybookstore.usim.edu.my/index.php? route= product/ product \& product $i d=371 \&$ search $=$ luganda. 16.07.2020.

21. Kirembwe R.A.H, Othman Dato' Hj. Mohamed, Mohd. Fauzi Muhamad and Arshad Abd. Samad, (2004). Effects of Cooperative Learning on Achievements in Arabic Writing Skills for Form Two Secondary Schoo Students in Selangor Malaysia. Ph.D Thesis: Universiti Putra Malaysia. UPM.

22. Kirembwe R.A.H, Yuslina M., Jaafar, M.N and Ahmad H (2013). Theoretical Model for Islamic Translation. Paper presented at Faculty of Major Language Studies: Penerbit USIM.

23. Krest Margie (1987). "Time on My Hands: Handling the Paper Load." English Journal, 76(8) December 1987. 37-42. EJ 367 295, National Standards: Oral and Written Communications. Washington Office of the State Superintendent of Public Instruction, Olympia, 1984. ED 297351, Washington.

24. Kussmaul, Paul. (1995). Training the Translator. John Benjamins Publishing Co.

25. Lörscher, W. (1992). Process-Oriented Research into Translation and Implications for Translation Teaching. TTR: Traduction, Terminologie Rédaction, 5(1), 145-161.

26. Marton, F. (1988). Describing and Improving Learning. In R.R. Schmeck (ed.) Learning Strategies and Learning Styles. New York: Plenum.

27. Marton, F., \& Saljo, R. (1976). On Qualitative Differences in Learning Outcome and Process. British Journal of Educational Psychology, 46, 4-11.

28. Massoud, M., F., (1988). Translate to Communicate, A Guide for Translators New York: Library of Congress Cataloging-in-Publication Data.

29. Mohammadi, F. (2014). Gender Ideology of Translators Implicated in Feminis Novels. International Journal of Comparative Literature and Translation Studies, 2(3), 36-41.

30. Patti Puckett (1997). Parents Helping Children Become Lifelong Readers Language Arts: It's A Complex Combination of Reading, Writing, Grammar And Listening Skills. The Atlanta Journal the Atlanta Constitution, Atlanta, Ga.; Nov 20, 1997; pg. J.13.

31. Pym, A., Orrego-Carmona, D., \& Torres-Simón, E. (2015). Status and Technology in The Professionalization of Translators. Market Disorder And The Return Of Hierarchy. Journal of Specialised Translation.25.33-53.

32. Robinson, D. (1997). Becoming a Translator: An Accelerated Course. London Routledge.

33. Robinson, D., \& Kenny, D. (2012). Becoming a translator: an introduction to the theory and practice of translation (3rd ed). London ; New York: Routledge.

34. Robinson, Douglas (2012) Becoming a Translator: An Introduction to the Theory and Practice of Translation, London and New York: Routledge.

35. Sanacore Joseph (1996). Supporting Language Arts Innovations that Endure Journal of Adolescent\& Adult Literacy, Newark Sep 1996; Vol. 40, Iss. 1; pg. 58 5 pgs.

36. Savory, Theodore Horace. (1957). The Art of Translation. London: Jonathan Cape Ltd. "Colocviul na ional de traduceri i literatur universal Stenograma.

37. Shafiee-Sabet, S. G., \& Rabeie, A. (2012). The Effect of the Translator's Gender Ideology on Translating Emily Bronte's Wuthering Heights. Journal of Teaching Language Skills, 3(3), 143-158.

38. Tymoczko, M. (2007). Enlarging Translation, Empowering Translators Manchester: St. Jerome Publishing.

39. Varzande, M \& Jadidi, E (2015). The Impact of Translators' Academic Experience on Their Translation Quality. 8(9), Canadian Center of Science and Education.

40. Varzande, M., \& Jadidi, E. (2015). The Effect of Translators' Emotional Intelligence on Their Translation Quality. English Language Teaching, 8(8), 104.

41. Venuti, L. (1995). The translator's invisibility: a history of translation. London New York: Routledge. Retrieved from http://site.ebrary.com/id/10097452

42. Weinstein, C., \& Mayer, R (1984). The Teaching of Learning Strategies. In M.C. Wittrock (Ed.), Handbook of Research on Teaching. New York: Macmillan. 